\title{
The First Decade of Informatics in Dutch High Schools
}

\author{
Nataša GRGURINA \\ University of Groningen, University Centre for Learning \& Teaching \\ Landleven 1, 9747 AD Groningen, the Netherlands \\ e-mail: n.grgurina@rug.nl

\section{Jos TOLBOOM} \\ University of Groningen, Faculty of Mathematics and Natural Sciences \\ Nijenborgh 4, 9747 AG Groningen, the Netherlands \\ e-mail: j.l.j.tolboom@rug.nl
}

Received: August 2007

\begin{abstract}
Informatics is currently being taught in high schools all over the world. In the Netherlands, where all students are expected to become computer literate in the lower grades of high school (Hulsen et al., 2005), it has been decided not to consider computer literacy as being part of Informatics. What, then, should be the content of the Informatics curriculum taught in the higher grades? What should be taught, how and to whom? How should students' achievements be assessed? The answers to these questions completely depend on defining what the objectives of teaching Informatics are. This case study will discuss these objectives, along with the content of the Dutch High School Informatics Curriculum, the experiences resulting from the initial implementation of this curriculum, including the setting in which Informatics presently finds itself, and in the course of this we will provide answers to the above questions.
\end{abstract}

Keywords: Dutch National Informatics Curriculum, Informatics in high schools, Informatics teaching experiences.

\section{The Dutch Educational System}

Fig. 1 shows the organization of the Dutch Educational System (Eurydice, 2007). After completing elementary school at the age of twelve, the students go on to different kinds of high school. The $\mathrm{VMBO}^{1}$ type of school, lasting four years, leads to vocational education. The HAVO type of school (senior secondary education) lasts five years and prepares students for higher professional education, while the VWO type of school (preuniversity education) lasts six years and is geared toward further education at a university. Secondary education ends with national exams covering nearly all the subjects taught. In this case study, we will be focusing solely on senior secondary education and preuniversity education. In these schools, every student has the same curriculum in grades

${ }^{1}$ VMBO: Voorbereidend middelbaar beroepsonderwijs: prevocational education 


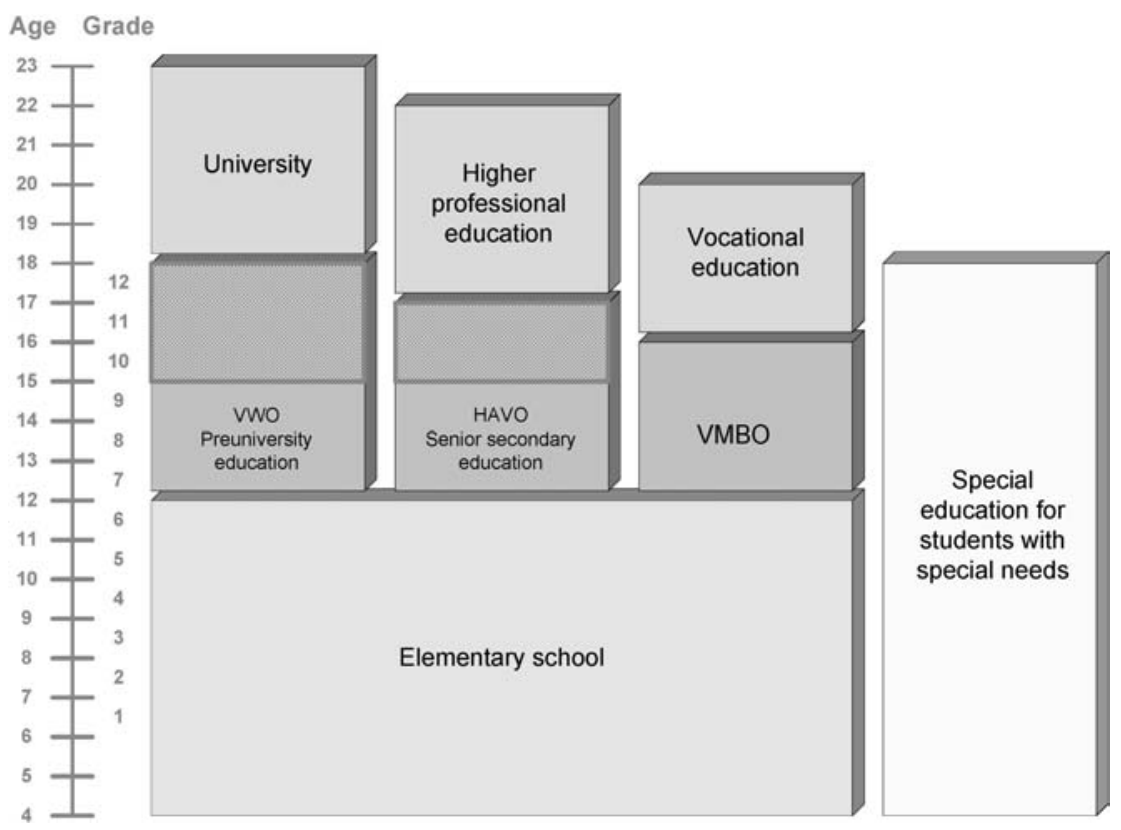

Fig. 1. The Dutch educational system. The shaded blocks represent those grades in which the students can choose Informatics.

seven through nine. While in the ninth grade, a student then chooses the curriculum to be followed in the subsequent higher grades. In 1998, education in these higher grades (10 and 11 for senior secondary education; 10 through 12 for pre-university education) went through major modifications (Ministry of Education, 1998b). It was decided that the curricula for all existing courses needed to be re-examined and that several new ones should be introduced, one of these being Informatics. Previously, in 1995, the Course Developer Group had been assigned the task of developing a curriculum for Informatics to be taught in grades ten and higher (Stuurgroep Profiel Tweede Fase Voortgezet Onderwijs, 1995). In this re-examination, all courses were categorized as either compulsory (e.g., the Dutch language, gym) or profile courses belonging to one of the four profiles a student can choose from (Culture and Society; Economy and Society; Nature and Health; Nature and Technology). In addition, there were to be "free" courses available to all students, one of these being Informatics. A student first chooses one of the four profiles. Then, in addition to these compulsory and profile courses, every student then takes one or two courses of his/her own choice, either a profile course from another profile or a "free" course.

\section{The Birth of Informatics in the Netherlands}

Before Informatics was introduced in the higher grades of high schools in 1998, only a few schools offered organized education in Informatics, and there it was organized by teachers on an individual basis. Only since the Course Developer Group was assigned 
the task of developing a curriculum for Informatics to be taught in grades ten and higher (Stuurgroep Profiel Tweede Fase Voortgezet Onderwijs, 1995), has structural attention been paid to Informatics at the high school level.

\section{Objectives}

The curriculum for this new Informatics course, regarded as a science discipline, was developed with several underlying principles in mind. Its aim was to provide students with an understanding of $\mathrm{IT}^{2}$ concepts, and to give them a sense of the potential and limitations of their use in the community as a whole, and, more specifically, of their use in their future careers (Hacquebard et al., 2005). The course was designed to be well within the capabilities of all students, regardless of whether the rest of their curriculum followed the social or the scientific profile. The result produced a course with a multidisciplinary nature, which exemplified how this nature could be applied to complex problems and structures. Furthermore, since Informatics was not a prerequisite for any subsequent study at the university/college level, there was no need for a national exam; all assessment was to take place at the high school level.

These considerations led to the following general objectives:

The Informatics course at the [. . . s secondary education level would be focused on providing students with:

- a view of Informatics and IT, and the relationship between these fields and other subject areas, as well as how they related to technology and society as a whole

- a picture of the role Informatics and IT would play in their education and career

- hands-on experience with Informatics and IT through:

- learning the basic concepts and skills of the subject,

- studying Informatics problems,

○ studying the structures of data processing systems,

- working on system development in groups;

and all this within the context of how Informatics could be applied in society as a whole (Stuurgroep Profiel Tweede Fase Voortgezet Onderwijs, 1995).

\section{The Position of Informatics in the High School Curriculum}

Informatics is not a compulsory course, nor does choosing to take it depend on any other courses in a student's curriculum. Since its introduction in 1998, it has consisted of 240 study hours for senior secondary education students, and 280 study hours for preuniversity education students. These study hours include all the time spent on learning in

${ }^{2}$ In this article, the terms Informatics and IT follow the definitions on page 9 (Van Weert and Tinsley, 2000). 
the classroom, as well as elsewhere. Informatics is designed to be taught no earlier than the tenth grade; that said, schools are free to decide in what grade(s) it should be taught ${ }^{3}$.

\section{The Informatics Curriculum}

All these considerations resulted in a curriculum that drew its inspiration from the 1994 UNESCO/IFIP curriculum (Van Weert and Tinsley, 1994); it was recommended that this curriculum cover four themes:

- Theme A: Informatics in perspective: Informatics should be examined from several vantage points (science and technology, society as a whole, education and career perspectives, and, finally, from a personal perspective); the result should then provide a student with a general overview. This theme was not intended to be taught on its own, but as an integral part of other themes.

- Theme B: Terminology and skills: in order to be able to develop Informatics skills, a student needs to acquire adequate knowledge and skills pertaining to hardware, software, organization, as well as to data and information and communication.

- Theme C: Systems and their structures concerns general information issues, various types of data processing systems, and the situations where these are normally used. It covers system theory, computer systems, real-life applications, information systems and new developments.

- Theme D: Usage in a context takes a look at practice. The study of system development and project management, including their social aspects, deals with the relationships between an "information issue" on the one hand, and the development and implementation of IT applications at all kinds of institutions, enterprises and application areas, on the other. This theme is all about letting the students themselves work with Informatics and IT, and encouraging the intertwining of their Informatics knowledge and skills with those skills acquired in other subjects in their curriculum (Stuurgroep Profiel Tweede Fase Voortgezet Onderwijs, 1995).

Taking these recommendations into account, the four themes were broken down into 53 specific terms, which would then comprise the Informatics curriculum ${ }^{4}$ (Ministry of Education, 1998a). A list of these terms is not included in this article because their description is quite extensive and substantial, but, more importantly, because they are in the process of becoming obsolete. They are being condensed into a shorter list of eighteen terms that are to comprise the curriculum for students entering the tenth grade from the

\footnotetext{
${ }^{3}$ The secondary school where the first author teaches Informatics interprets this as follows: in senior secondary education there are two weekly 45-minute lessons in the tenth and eleventh grades; in pre-university education two weekly 45-minute lessons in the eleventh grade and three in the twelfth grade.

${ }^{4}$ The curricula for the two types of secondary school mentioned in this article, as far as the content is concerned, differ only in the details of a small number of terms (SLO, 1998). However, it is suggested that in the HAVO type of school the emphasis should be placed on practical work, while in the VWO type of school the approach should be more abstract and theoretical (Stuurgroep Profiel Tweede Fase Voortgezet Onderwijs, 1995).
} 
fall of 2007 onwards (Schmidt, 2006, pp. 43-45). This new 2007 curriculum is given below:

Informatics Curriculum HAVO/VWO (senior secondary education/pre-university education)

The exam:

The exam takes the form of an individual school exam.

The curriculum consists of the following themes:

Theme A Informatics in perspective

Theme B Terminology and skills

Theme C Systems and their structures

Theme D Usage in a context

\section{The school exam:}

The school exam is associated with Themes A through $\mathrm{D}$; and in cases where the authorities so decide, it can also include other subject matter that does not necessarily need to be identical for all students.

\section{The subject matter:}

\section{Theme A: Informatics in perspective}

Sub-theme A1: Science and Technology

1. The student should be familiar with the history of Informatics and IT, their current use and the prospects for future development.

Sub-theme A2: Society

2. The student should be familiar with the role Informatics and IT play in the developments taking place in society, both in the past and the present.

Sub-theme A3: Study and Career

3. The student should be familiar with the specific functions and jobs performed by Informatics and IT specialists, and with the role Informatics and IT play in vocational education and occupations in general. The student should be able to assess to what degree his own abilities and interests correspond with these.

Sub-theme A4: The Individual

4. The student should master the professional work methods that Informatics and ITC specialists use, especially those concerning working on a project basis. He should be familiar with the moral values involved in the use of Informatics and IT.

\section{Theme B: Terminology and skills}

Sub-theme B1: Data representation in a computer

5. The student should be able to describe and use common digital data encoding.

Sub-theme B2: Hardware

6. The student should be familiar with the operational functions of a computer, its hardware and common peripheral devices, and should be able to describe the relationships among these functions. 
Sub-theme B3: Software

7. The student should be familiar with simple data types, program structures and programming techniques.

Sub-theme B4: Organizations

8. The student should have a global picture of how businesses are structured. He should be familiar with the characteristics of project organization and should be able to explain why a particular type of organization is chosen when a company's information system undergoes major modifications.

\section{Theme C: Systems and their structures}

Sub-theme C1: Communication and Networks

9. The student should be familiar with the topological structure and communication layers of a network, and their characteristics. He should also be capable of describing a simple communications protocol, differentiating between its elements and describing them. Furthermore, he should be aware of the security aspects of the Internet.

Sub-theme C2: Operating Systems

10. The student should be familiar with the basic functions of the most common operating systems pertaining to the management of CPU time, memory, data storage media, peripheral devices, and access rights.

Sub-theme C3: Systems in Practice

11. The student should be familiar with the characteristics of, and distinction among real-time systems, expert systems, simulation systems and embedded systems.

Sub-theme C4: Development of Information Systems

12. The student should have a global picture of system development stages, and their related actions and products.

Sub-theme C5: Information Flow

13. The student should be capable of describing information flow in a small (business) organization.

Sub-theme C6: Information Analysis

14. The student should be able to analyze information and information requirements and build/adjust the data model accordingly.

Sub-theme C7: Relational Databases

15. The student should be able to name the elements of a relational scheme and describe their meaning. He should be able to translate an information question into a relational database query language command. He should be familiar with the characteristics and aspects of data management systems, and he should be able to name them and use them for specific systems. (Only pre-university education)

Sub-theme C8: Human-Computer Interaction

16. The student should be able to identify the human-computer interaction element in information systems. He should be familiar with its characteristics and he should be able to recognize and utilize key criteria in the development of user dialogs. 
Sub-theme C9: System Development Lifecycle

17. In a simple system development lifecycle, the student should be capable of assessing its progress, testing a prototype, checking whether the final product meets the client's specifications, and assessing whether the system complies with the requirements and wishes of the end user.

\section{Theme D: Usage in a context}

18. The student should be familiar with the methods and procedures of project management, as well as the project aspects of system development (Schmidt, 2006).

One example is illustrative of the way the 1998 curriculum has evolved into the curriculum of 2007. As far as software is concerned, the 2007 curriculum contains only one term:

Sub-theme B3: Software. The student should be familiar with simple data types, program structures and programming techniques (Schmidt, 2006).

The 1998 curriculum contained three terms (21 through 23) concerning software:

Theme B: Terminology and skills [...]

Sub-theme: Software

Sub-sub-theme: Programs as structured solutions

The student should be able to:

21) split a problem up into smaller problems. In solving a problem, he should be able to utilize the basic concepts of loops, conditional statements and the execution order. He should be able to use the principles of a structuring technique and describe the relationship between a structure and the corresponding program;

22) describe a number of simple data types and use them in programs (senior secondary education);

22) describe a number of simple data types and use them in programs (pre-university education). The student should also be able to describe the parameter passing between the procedures.

\section{Sub-sub-theme: Software usage}

23) The student should be able to make a distinction among the various usage possibilities of software applications. He should be able to indicate what program to use in a particular situation. He should be able to perform simple operations with some of them (SLO, 1998).

Thus a comparison of the Dutch 2007 curriculum with the 2000 UNESCO/IFIP curriculum (Van Weert and Tinsley, 2000) is called for (Table 1).

Several terms in the Dutch 2007 curriculum do not correlate explicitly with the UNESO/IFIP curriculum (Table 2).

Unit B - Application of IT in Subject Areas is not seen as a task that should be performed in the context of an Informatics course. The hands-on nature of the Informatics course, together with its general objectives as mentioned earlier in this article, does, how- 
Table 1

Comparison of the UNESCO/IFIP curriculum to the Dutch 2007 curriculum

\begin{tabular}{|c|c|}
\hline UNESCO/IFIP & The Dutch 2007 curriculum \\
\hline Unit A1 - Basic concepts of IT & $\begin{array}{l}\text { Sub-theme B2: Hardware } \\
\text { Sub-theme C2: Operating Systems }\end{array}$ \\
\hline $\begin{array}{l}\text { Unit A2 - Using the Computer and } \\
\text { Managing Files }\end{array}$ & $\begin{array}{l}\text { Computer literacy program in the lower grades of secondary } \\
\text { education (Netelenbos, 1998) }\end{array}$ \\
\hline Unit A3 - Word Processing & Idem \\
\hline Unit A4 - Working with a Spreadsheet & Idem \\
\hline Unit A5 - Working with a Database & Sub-theme C7: Relational Databases \\
\hline $\begin{array}{l}\text { Unit A6 - Composing Graphical } \\
\text { (Re)presentations }\end{array}$ & $\begin{array}{l}\text { Computer literacy program in the lower grades of secondary } \\
\text { education }\end{array}$ \\
\hline $\begin{array}{l}\text { Unit A7 - Computers and Communica- } \\
\text { tion }\end{array}$ & Idem \\
\hline Unit A8 - Social and Ethical Issues & $\begin{array}{l}\text { Sub-theme A1: Science and Technology } \\
\text { Sub-theme A2: Society } \\
\text { Sub-theme A4: The Individual }\end{array}$ \\
\hline Unit A9 - Jobs and/with IT & Sub-theme A3: Study and Career \\
\hline Unit E1 - Spreadsheet Design & $\begin{array}{l}\text { Computer literacy program in the lower grades of secondary } \\
\text { education }\end{array}$ \\
\hline Unit E2 - Database Design & $\begin{array}{l}\text { Sub-theme A4: The Individual } \\
\text { Sub-theme C7: Relational Databases }\end{array}$ \\
\hline $\begin{array}{l}\text { Unit SP1 - Introduction to } \\
\text { Programming }\end{array}$ & Sub-theme B3: Software \\
\hline Unit SP2 - Top-Down Program Design & $\begin{array}{l}\text { Goes beyond the scope of the standard curriculum. It may be } \\
\text { taught as a part of a school's enrichment program. }\end{array}$ \\
\hline $\begin{array}{l}\text { Unit GS1 - Foundations of Program- } \\
\text { ming and Software Development }\end{array}$ & $\begin{array}{l}\text { Sub-theme C4: Development of Information Systems } \\
\text { Sub-theme C9: System Development Lifecycle } \\
\text { Theme D: Usage in a context } \\
\text { As a whole, this unit goes beyond the scope of the standard } \\
\text { curriculum. It may be taught as a part of a school's enrichment } \\
\text { program. }\end{array}$ \\
\hline $\begin{array}{l}\text { Unit GS2 - Advanced Elements of Pro- } \\
\text { gramming }\end{array}$ & $\begin{array}{l}\text { This matter may comprise part of a school's enrichment pro- } \\
\text { gram. }\end{array}$ \\
\hline $\begin{array}{l}\text { Unit VS1 - Business Information Sys- } \\
\text { tems }\end{array}$ & $\begin{array}{l}\text { Sub-theme C4: Development of Information Systems } \\
\text { Sub-theme C5: Information Flow } \\
\text { Sub-theme C6: Information Analysis } \\
\text { Sub-theme C7: Relational Databases } \\
\text { Sub-theme C8: Human-Computer Interaction } \\
\text { Sub-theme C9: System Development Lifecycle }\end{array}$ \\
\hline Unit VS2 - Process Control Systems & $\begin{array}{l}\text { Sub-theme C9: System Development Lifecycle } \\
\text { As a whole, this unit goes beyond the scope of the standard } \\
\text { curriculum. It may be taught as part of a school's enrichment } \\
\text { program. }\end{array}$ \\
\hline Unit VS3 - Project Management & Sub-theme C4: Development of Information Systems \\
\hline
\end{tabular}


Table 2

Comparison of the Dutch 2007 curriculum to the UNESCO/IFIP curriculum

\begin{tabular}{ll}
\hline The Dutch 2007 curriculum & UNESCO/IFIP curriculum \\
\hline Sub-theme B1: Data representation in a computer & $\begin{array}{l}\text { Not explicitly mentioned. Probably considered as } \\
\text { a part of IT Literacy. }\end{array}$ \\
\hline Sub-theme B4: Organizations & $\begin{array}{l}\text { Not mentioned in such detail. Some references are } \\
\text { made in the VS Units. }\end{array}$ \\
\hline Sub-theme C1: Communication and Networks & Goes beyond networks mentioned in Unit A. \\
\hline Sub-theme C3: Systems in Practice & Not mentioned in such detail. \\
\hline Sub-theme C8: Human-Computer Interaction & $\begin{array}{l}\text { Not mentioned in such detail. Some reference is } \\
\text { made in the VS1 Unit. }\end{array}$ \\
\hline
\end{tabular}

ever, encourage work on projects that go beyond the boundaries of a particular (Informatics) course. ${ }^{5}$

The curriculum makes clear that the objectives of the Informatics course are primarily the study of Informatics in the broadest sense of the scientific discipline. Computer literacy is assumed to have been achieved earlier on, and the use of computers as teaching aids in other courses falls beyond the scope of Informatics. In Israel, for example, curriculum developers chose to design a secondary education program that, although fundamental in character, focused on programming:

"algorithmics is the central subject of study" (Gal-Ezer et al., 1995, pp. 76).

Both the 1998 and 2007 curricula are accompanied by documentation (Hartsuijker, 1999; Schmidt, 2006) suggesting how to implement them. Table 3 suggests the number of hours to be allocated to the study of each of the terms.

It has been suggested that the 2007 curriculum be implemented in the form of a number of core modules that are the same for both senior secondary education and pre-university education, along with a number of distinct enrichment modules (Schmidt, 2006).

It is interesting to note that, although programming (the practical translation of "algorithmics") is considered a dominant theme in Informatics by the Informatics community worldwide (Gal-Ezer et al., 1995), this is not reflected in the Dutch curriculum. Even in the best-case scenario, less than one quarter of the time available is supposed to be dedicated to programming.

\section{Teaching Informatics in the Classroom}

In 1998 the major modifications made to education in the upper grades of high schools came with recommendations for organizing classroom work in a different manner.

\footnotetext{
${ }^{5}$ IT is often used in Dutch classrooms: Office Applications, CD-ROMs accompanying the textbooks, Virtual Learning Environments, specific application software, etc. (Hulsen et al., 2005) IT in Dutch schools, in general terms, is a topic that goes beyond the scope of this article.
} 
Table 3

Suggested study load per term. PM = pro memorie; these study hours are already covered by other terms and do not count toward the total (Schmidt, 2006, pp. 31)

\begin{tabular}{|c|c|c|c|c|c|c|}
\hline \multirow[b]{2}{*}{ Sub-theme } & \multirow[b]{2}{*}{ Term } & \multicolumn{2}{|c|}{$\begin{array}{l}\text { The } 1995 \text { curriculum } \\
\text { (put into practice since 1998) }\end{array}$} & \multicolumn{3}{|c|}{ Suggestion for the 2007 curriculum } \\
\hline & & $\begin{array}{c}\text { Senior } \\
\text { secondary } \\
\text { education }\end{array}$ & $\begin{array}{l}\text { Pre-university } \\
\text { education }\end{array}$ & Core & $\begin{array}{l}\text { Enrichment } \\
\text { senior } \\
\text { secondary } \\
\text { education }\end{array}$ & $\begin{array}{c}\text { Enrichment } \\
\text { pre-university } \\
\text { education }\end{array}$ \\
\hline A1 & 1 & $5 \mathrm{pm}$ & $5 \mathrm{pm}$ & 5 & & \\
\hline A2 & 2 & $5 \mathrm{pm}$ & $5 \mathrm{pm}$ & 5 & & \\
\hline A3 & 3 & 5 & 5 & & $\mathrm{pm}$ & $\mathrm{pm}$ \\
\hline A4 & 4 & $20 \mathrm{pm}$ & $20 \mathrm{pm}$ & & $\mathrm{pm}$ & $\mathrm{pm}$ \\
\hline B1 & 5 & 8 & 8 & 8 & & \\
\hline B2 & 6 & 8 & 8 & 7 & $\mathrm{pm}$ & pm \\
\hline B3 & 7 & 24 & 44 & 40 & & 30 or 60 \\
\hline B4 & 8 & 5 & 5 & 5 & & \\
\hline $\mathrm{C} 1$ & 9 & 20 & 20 & 10 & $\mathrm{pm}$ & $\mathrm{pm}$ \\
\hline $\mathrm{C} 2$ & 10 & & & 10 & $\mathrm{pm}$ & $\mathrm{pm}$ \\
\hline C3 & 11 & 15 & 15 & 10 & & \\
\hline $\mathrm{C} 4$ & 12 & 61 & 77 & 10 & $\mathrm{pm}$ & $\mathrm{pm}$ \\
\hline $\mathrm{C} 5$ & 13 & & & 15 & & \\
\hline C6 & 14 & & & 25 & & 0 or 30 \\
\hline $\mathrm{C} 7$ & 15 & & & 20 & & 30 \\
\hline $\mathrm{C} 8$ & 16 & & & 20 & $\mathrm{pm}$ & $\mathrm{pm}$ \\
\hline C9 & 17 & & & 10 & & \\
\hline $\mathrm{D}$ & 18 & 60 & 60 & & 60 & 60 \\
\hline Free & & 24 & 28 & & 60 & 90 \\
\hline Obsolete & & 10 & 10 & & & \\
\hline Total & & 240 & 280 & 200 & 120 & 240 \\
\hline
\end{tabular}

The students were to be given more freedom and responsibility for their own learning process. Furthermore, obtaining factual knowledge was no longer to be the sole objective of attending school. Acquiring skills and competences became an objective as well (Stuurgroep Profiel Tweede Fase Voortgezet Onderwijs, 1994).

This approach to teaching was a good fit for Informatics. Students, it was suggested, should spend a lot of time doing practical work and working on projects, mainly solving Informatics problems. IT applications, in fact, are found in a wide range of areas in "society," and they are always about processing, organizing and communicating large amounts of relevant data. Moreover, IT problems in practice are so intricate and extensive that one person cannot solve them alone, even when the issues in question are relatively simple. Keeping in mind that Informatics education was not primarily meant to mirror professional practice, these five starting points for classroom teaching were suggested:

Informatics education should be about students: 
1. Learning about the field of Informatics through the acquisition of factual knowledge and skills relative to the ways of thinking and working methods found within Informatics.

2. Learning to apply Informatics through solving Informatics problems, using the Informatics knowledge and skills acquired.

3. Learning to deal with interdisciplinary problems: learning to use Informatics knowledge and skills in an interdisciplinary context.

4. Learning to cooperate: learning to practice Informatics in a structured collaborative way.

5. Learning to reflect: learning how to learn from the previous four points independently [...] (Hartsuijker et al., 2000).

\section{Assessment}

These points of view are reflected in the way the curriculum prescribes assessment and this in turn influences the way Informatics is taught in the classroom. There is no national exam $^{6}$ and all assessments take place at the school level in the form of a so-called school exam. A student's Informatics school exam is a portfolio containing the following parts ${ }^{7}$ :

A. Written examination.

B. Practical assignments. The student is to do practical work and come up with a result. When relevant, the process itself is taken into account by giving credit for the documentation describing the processes involved.

C. Project: system development. This is a larger practical assignment to be carried out in groups of at least three students. Each student is expected to work for approximately sixty hours on this project.

D. Activities. Taking part in activities intended to provide a picture of the educational and career perspectives in which IT plays an essential role.

The first version of the 1998 curriculum explicitly states that Part $A$ should contribute forty percent towards the final grade, Parts $B$ and $C$ thirty percent each, while Part $D$ only needs to be covered up to a satisfactory level (SLO, 1998). Soon, however, this was all to change and nowadays the assessment is as follows: Part $D$, activities, has been removed. Part $C$, project, has become optional. And Part $A$, written examination, now contributes to up to fifty percent of the final grade (Ministry of Education, 1998a; Ministry of Education, 2000). The practical nature that the course in Informatics was intended to have is thus

\footnotetext{
${ }^{6}$ For an explanation of the Dutch national secondary school exam, see http://194.78.211.243/Eurybase/Application/gettext.asp?tablename=NL_EN_5 $\& i d=38 \&$ nparam $=0$.

${ }^{7}$ For senior secondary education, see

http: / / www. eindexamen.nl/9336000/1/j9vvgodkvkzp4d4/vg41h1jtpgy4/f= /bestand.doc (retrieved August 2007)

For pre-university education, see

http: / / www. eindexamen.nl/9336000/1/j9vvgodkvkzp4d4/vg41h1jtpgy5/f= /bestand. doc (retrieved August 2007).
} 
emphasized once again by prescribing that practical assignments and/or a project should contribute to at least fifty percent of the final grade.

For the 2007 curriculum it was suggested that the assessment should contain the following parts:

A. Written examination.

B. Practical assignments.

C. Project.

Part A should contribute at least ten percent and at most fifty percent towards the final grade, and part $\mathrm{B} / \mathrm{C}$ at least fifty percent and at most ninety percent. The grade for part $\mathrm{B} / \mathrm{C}$ is the arithmetic mean of the grades for parts B and C (Schmidt, 2006).

\section{Teacher Training}

Prior to the 1998 modifications to the educational system in the Netherlands, there were a small number of teachers teaching Informatics at there own initiative. These lessons were optional and consisted mostly of programming activities. The teachers developing these activities were usually mathematics or science teachers (Tolboom, 1999). There was no formal Informatics teacher training. When the decision was taken to introduce Informatics in the upper grades of senior secondary education and pre-university education, there were a lot of concerns. One of the most urgent was that there were no teachers to teach this course. In considerable haste, $\mathrm{CODI}^{8}$, a consortium of 12 universities and institutes for higher professional education, was set up to join forces in training teachers, who were to be responsible for the implementation of Informatics in their schools (Table 4). In the period between 1998 and 2005, those schools that planned to introduce Informatics sent

Table 4

CODI program

\begin{tabular}{lc}
\hline Course & ECTS \\
\hline Orientation on Informatics & 3.5 \\
Computer Architecture and Operating Systems & 0.7 \\
Visual Programming with Java & 5.7 \\
Information Systems: Modeling and Specifying & 5 \\
Databases & 0.7 \\
Telematics & 3.5 \\
Software Engineering & 5 \\
Human-Machine Interaction & 1.4 \\
Programming Paradigms and Methods of Information System Development & 1.4 \\
Didactics of Informatics & 5.7 \\
Informatics Projects & 2.8 \\
Practical Teaching Assignment & 10 \\
\hline
\end{tabular}

\footnotetext{
${ }^{8} \mathrm{CODI}$ is the Dutch acronym for the Informatics Teacher Education Consortium.
} 
a teacher each for retraining. Whereas elsewhere prospective Informatics teachers were expected to posses extensive knowledge of the subject (Gal-Ezer, 1995), these teachers were by no means required to have any prior knowledge of Informatics and were only expected to be computer literate at a satisfactory level. In order to obtain their teaching license for Informatics they had to complete a two-year program of about 45 ECTS. This program consisted of the following parts: (Ministry of Education, 1998a, pp. 22-24).

For a description of this curriculum from the perspective of the practice of teaching, see (Dirks and Tolboom, 2000). In 2005 CODI was dismantled leaving a void since no other way was set up to train and license Informatics teachers. As of 2006, five universities $^{9}$ in the Netherlands now offer secondary school Informatics teacher education as a Master's degree program.

\section{The First Decade of Teaching Informatics}

With all these various objectives, points of view, considerations, recommendations, as well as the curriculum itself in mind, one question arises: how does this all work in practice?

Informatics has been monitored from the very outset in 1998, and there have been five detailed reports describing the resulting state of affairs (Hartsuijker, 2001; Hartsuijker, 2002; Hartsuijker, 2003; Hartsuijker, 2004; Schmidt, 2008). Other than these reports, there has been no significant scientific research into any of the aspects of Informatics in high schools in the Netherlands.

In the Netherlands, not all schools offer Informatics. During the period 2002-2006, out of about 474 independent schools, the percentage of schools that do offer Informatics has remained fairly constant at around sixty percent. There are indications that since 2007, this percentage has been rising (Schmidt, 2008). During the CODI era, 369 candidate Informatics teachers began their studies, and 336 (91\%) graduated (CODI, 2005).

During the period 2000-2006 the number of high school graduates with Informatics has been on the decrease and seems now to be stabilizing at around ten percent (of the total student population) (Schmidt, 2008).

Setting aside the start-up difficulties in the beginning, a clear picture of the problems encountered and of the accomplishments realized has emerged. From the teachers' point of view, the curriculum was ostensibly too broad and extensive (in terms of available teaching time), forcing them to skip parts of it. Concerning this same issue, they experienced difficulty in judging the amount of attention and time to be given to particular terms. The three textbooks ${ }^{10}$ (Bergervoet et al., 2001; Meijer et al., 2001; Van der Laan et al., 2001) on the market did not help much in solving this problem, since each of them

\footnotetext{
${ }^{9}$ See:

http://www.ieni.org/confarchief/conf2006/presentations/NicovanDiepen

_IenI-LerarenopleidingInfNvD.ppt and

http://www.rug.nl/uocg/onderwijs/lerarenopleiding/index

${ }^{10}$ These textbooks all consist of several separate volumes and are accompanied by CD-ROMs and dedicated websites.
} 
had different approaches to the subject matter. Therefore, many teachers were forced to resort to writing their own teaching material (much of which has now been made available to other teachers through the online community on www. informaticavo.nl). This situation, however, was not just perceived as a problem; it was also seen as an opportunity to pay more attention to the subject matter that students and/or teachers themselves found interesting. With this in mind, many teachers were happy that there was no national exam putting pressure on them to work out minutely all of the 53 curriculum terms in the class. In a country where we are used to national exams that ensure the level of students' accomplishments and then serve as gateways to higher education, this has caused quite understandable concerns. What guarantees are there that students attending different schools will end up acquiring a similar body of knowledge? At the moment, since Informatics is not a prerequisite for any study in higher education, this does not really matter. However, there is an occasional discussion about whether there should be a national exam for Informatics. The details of this discussion will be described in the Discussions section.

Bearing in mind that virtually all of the Informatics teachers come from a nonInformatics background, it is not surprising to see differing interpretations of the curriculum. In some cases Informatics in the classroom has ended up being treated as an exact science, and in some cases the emphasis is put on the use of particular software applications, none of which is in line with curriculum objectives. The picture that students, their parents, and even guidance counselors and other school officials had about Informatics was often limited and did not fit the broad perspective it was supposed to provide. The experiences of the authors is a good example: while teaching Informatics in the tenth grade, they encountered students who expected to spend the lessons doing "computering," by which they meant doing unspecifiable stuff, with the Internet playing a major role in whatever this was. When asked what they expected to learn in Informatics, they could not formulate a clear answer. And then there were those students who already knew so much that they didn't even consider taking Informatics because they thought they already knew it all. A solution to this problem was sought by providing instructive lectures (CODI, 2006) to ninth-grade students about the Informatics course right at the very moment when they were set to decide which courses to take in the higher grades.

Another difficulty encountered came out of the very foundation upon which the whole course of Informatics was built. On the one hand, this course was meant to be accessible to all students without any prerequisite. On the other, however, the students were supposed to acquire an overview of and hands-on experience with all aspects of Informatics. When it came to programming, for example, many students had difficulties with complex programming languages such as Java, as had many of their teachers without an Informatics background when they had been faced with learning this programming language during the CODI training (Tolboom, 1999). Information modeling using a CASE tool for FCO-IM ${ }^{11}$ (Bakema et al., 2002) was another stumbling block where many students went astray. Obviously, then, occurrences such as these have played a part in making teachers choose their own interpretations of the curriculum.

\footnotetext{
${ }^{11}$ FCO-IM stands for Fully Communication-Oriented Information Modelling
} 
Looking on the bright side, both teachers and students appreciated this practical approach to teaching. The practical assignments were highly motivating, and proved to be very valuable by encouraging students to cooperate with each other and take responsibility for their own achievements. They made differentiation among the students possible. They were also illustrative of the practical nature of Informatics. The way Informatics is taught in the classroom is a fine example of the new didactic approach behind the modified secondary education system introduced in 1998.

One can get an impression of what is going on in classrooms all over the country by taking a look at the quite lively online community on www. informaticavo.nl. The growing diversity of topics found there is remarkable. A quick look at the collection of tests on programming submitted to the site, for example, shows that the subject is apparently being taught using Visual Basic, Logo, NQC for Lego Mindstorms, Java, Gamemaker and Delphi. The practical assignments submitted also show large variations as well, for example, Build a Company Website; Make a Database for the Administration of a Football Club; Build a User-Friendly Interface for an Information System ${ }^{12}$; and from the first author's own classroom: utilize the debating skills acquired in language classes to debate a particular ethical issue concerning IT.

This diversification and growth are not surprising in a discipline undergoing such rapid changes and new developments, and so now is a good time to pose the question: where do we go from here?

\section{Informatics from 2007 Onward}

As of the fall of 2007, education in the higher grades of secondary education in the Netherlands has once again been subjected to certain modifications. The leitmotif is that schools should be granted more autonomy and choice in the way they organize education, and so make the whole of education more manageable for schools through, among other things, streamlining the amount of time each course is allocated. Again, these modifications are favorable for Informatics in general and for individual schools in particular. To begin with, as already mentioned in Table 3, the hours allocated to Informatics are 320 for senior secondary education and 440 for pre-university education. Furthermore, the curricula for all the subjects have been simplified so as to decrease the number of terms, and the terms themselves are no longer described in such great detail. For Informatics this means that, following recommendations based on classroom experience (Hartsuijker, 2004), no new terms have been added. The result is that the new curriculum now consists of the eighteen terms listed in the section entitled The Informatics curriculum.

There is more good news for Informatics. Not only are schools being given total freedom in designing their assessment procedures, they are also now being encouraged to teach topics that extend, deepen, and go beyond the curriculum terms (Tweede Fase Adviespunt, 2006).

\footnotetext{
${ }^{12}$ See www.informaticavo.nl/scripts/lesmateriaal.php
} 
And last but not least, there is news from the research side. The Technical University of Eindhoven (TUE) and the Open University of the Netherlands have begun a research project to analyze and summarize the relevant research literature for pedagogical content knowledge (PCK) for Informatics teachers and to link this PCK to practice in the Dutch classroom. The aim is to create an inventory of research-based best-practice characteristics.

In spite of all this good news for Informatics in general, the prospects for a bright future are hampered by various problems.

The publishers of two of the three textbooks (Bergervoet et al., 2001; Meijer et al., 2001) have recently ${ }^{13}$ decided to cease publication of their textbooks. The authors of these textbooks are now taking steps to continue development of the teaching materials and to make them available on line. There are university-based projects ${ }^{14}$ aimed at developing teaching materials as well. However, together these initiatives do not provide enough teaching material to meet the needs of the increased number of study hours, leaving the teachers to their own devices once again.

There are many non-licensed teachers teaching Informatics - an estimated two out of five - the same as was reported in Israel back in the 1990s (Gal-Ezer, 1995), and this situation does not look like it will be changing any time soon (Schmidt, 2008). Despite the fact that since the fall of 2006 there are five universities in the Netherlands ${ }^{15}$ where one can become a licensed high school Informatics teacher, the numbers of students do not nearly match the demand from schools. The reasons for this are numerous and complex. In order to become a licensed Informatics teacher, as a rule one needs to have a Bachelor's degree in Informatics, and then follow a Master's in Education and Communication. Almost none of the Informatics Bachelor's students take this route because a career in education is often perceived as being of low social status, coupled with low pay and presenting almost no career prospects, while the booming economy has so much more to offer. On top of all that, a typical school does not have enough weekly Informatics lessons scheduled to offer full-time employment to an Informatics teacher. On the other hand, a lot of the people who do want to become licensed Informatics teachers have an IT background and/or are licensed to teach other subjects, but do not qualify for the EC Master's due to a lack of a formal Informatics Bachelor's degree. Needless to say, this paradoxical situation does no good for Informatics as a whole.

Another problem, probably the toughest of them all, and experienced internationally as well (Downes, 2007), is the perception of Informatics held by the whole of the population, with education policy makers regrettably being no exception. Two examples illustrate this unfortunate situation:

The Ministry of Education is looking ahead and considering the future of educational alterations and reforms, and to this end it set up an advisory board and asked it to formu-

\footnotetext{
${ }^{13}$ In 2006 and 2007

${ }^{14}$ At http: / / www. hetisamsterdam.nl/ one can see an interesting example: university lecturers and secondary school teachers of Informatics working together to develop educational content for Informatics at the secondary level.

${ }^{15}$ University of Utrecht, University of Groningen, University of Twente, Technical University of Delft, Technical University of Eindhoven.
} 
late a vision for future educational developments. This board consisted of 33 members, mostly university professors, several high school teachers, along with a few policymakers and students. None of them had any Informatics background, which, in our opinion, is regrettable, because the advice the board presented to the Ministry paid scarcely any attention to Informatics education, barely mentioning it at all. The 232-page document mentions Mathematics 263 times, and Informatics 10 times (Profile board Nature \& Profile board Society, 2007).

Another example is even more serious in our opinion. One of the new courses introduced as part of the educational modifications in 2007 is NLT (Nature, Life and Technology). It is meant to be a cross-subject science course offered to those students choosing one of the Nature profiles. ${ }^{16}$ Even though the proposed NLT curriculum ${ }^{17}$ contains terms pertaining to IT and bioinformatics, Informatics teachers are not licensed to teach it, while the teachers of mathematics, physics, chemistry, biology and geography are.

\section{Discussions}

Concerns about the future of Informatics in Dutch high schools are reflected in a number of discussions that are going on at the moment. One of the hot issues is the question of whether or not to introduce a national exam. In the 2007 report on the implementation of Informatics (Schmidt, 2008), a survey of Informatics teachers reported the following results (Table 5).

When asked about their reasons, the great majority of opponents answered that they feared losing the freedom to design the content of the subject they taught, followed by the argument that Informatics was not a prerequisite for any subsequent study at the highereducation level. The advocates of a national exam posited that it might help strengthen the position of this school subject in the curriculum alongside all the other school subjects. They also felt that it would lessen the differences in the levels of accomplishment now found in students. As a result, higher education would have a better picture of what

Table 5

Informatics teachers' survey results on the question of a national exam

\begin{tabular}{lc}
\hline Answer & Score \\
\hline As far as I am concerned, a national exam is out of the question & $29.2 \%$ \\
As far as I am concerned, a national exam is only to be considered under strict conditions & $26.1 \%$ \\
I am not an advocate of a national exam, but I'm not against it either & $16.9 \%$ \\
I can see the advantages of a national exam & $13.8 \%$ \\
I truly believe in a national exam & $13.8 \%$ \\
\hline
\end{tabular}

\footnotetext{
${ }^{16}$ For the description of profiles, see The Dutch Educational System section.

${ }^{17}$ For a description of the NLT curriculum, see

http://www. betavak-nlt.nl/bezoeker/00005/00001/00001/, retrieved August 2007
} 
to expect from first-year students who had taken Informatics in high school. The advocates assumed that only about sixty percent of the subject matter needed to be examined by means of a national exam, because only a limited number of curriculum terms were suitable for practical examination. Furthermore, aspects of the curriculum, such as cooperation, task-sharing and working on projects, were difficult to examine in a national exam. Therefore, a national exam could, just as in the case of many other school subjects, contain about $60 \%$ of the curriculum (Schmidt, 2008).

Informatics teachers were obviously not in favor of a national exam, but they were not the only party involved in this discussion. Universities did advocate one. National politics, with its tendency to want to exercise a controlling influence on the output quality of secondary education, saw a national exam as a suitable instrument to do just that.

Still another discussion surrounding Informatics is the question of whether to make Informatics compulsory. A slight majority of Informatics teachers think that Informatics should be compulsory in the lower grades of high school so that students will have a better picture of this subject when they choose their profile and the curriculum to follow from the tenth grade on. Informatics in the higher grades would then be able to consist of several modules, since the students would already have a foundation to build on. In addition, this would create a continuous line from elementary school all the way through to the higher grades of secondary education. About one quarter of the teachers, however, were opposed to this idea. Other scenarios, such as a common core course for all students, with separate modules for each profile, or even a distinct Informatics course for each of the profiles, can count on roughly equal numbers of advocates and opponents, or just simply a majority of opponents.

\section{Concluding Remarks}

During the first decade of Informatics in Dutch high schools, the objectives outlined in the 1990s do seem to have been achieved. What Informatics will look like in its second decade depends on the outcome of the discussions about the introduction of a national exam and whether to make it a compulsory subject, as well as on the repercussions from the fact that many Informatics teachers are not licensed and/or adequately trained. Furthermore, it is not yet clear whether the government intends to reform education in the upper grades of high school again, and if so, what consequences this will have for Informatics. And, last but not least, we believe that clearing up the misconceptions surrounding Informatics and bringing proper attention to bear on its significance would contribute to a bright(er) future for Informatics education.

\section{Acknowledgements}

This article draws heavily on the work of Ard Hartsuijker from the Dutch Organization for Curriculum Development (In Dutch: SLO) and his successor Victor Schmidt. 


\section{References}

Bakema, G., Zwart, J.P. and Van der Lek, H. (2002). Fully Communication Oriented Information Modelling, FCO-IM. Ten Hagen \& Stam, The Hague, the Netherlands.

Bergervoet, P., Boon, P., Commandeur, K., Smeets, D., Van der Heijden, T. and Vorstenbosch, P. (2001). Informatica (2 ed.). Edu'Actief, Meppel.

CODI (2005). Informatics: Something with Computers? http://www.informaticavo.nl/scripts/voorlichting.php

CODI (2006). Het (profiel-) keuzevak Informatica in de Tweede Fase van havo en vwo vanaf 2007. http://www.informaticavo.nl/voorlichting/informaticadocenten.doc

Dirks, F. and Tolboom, J. (2000). CODI curriculum from the perspective of the teacher's practice. Tinfon, 9 , 104-107.

Downes, T. (2007). Informatics Education: A Case Study of the Confusions and Complexities of the Intended and Enacted Curriculum in NSW Secondary Schools. In Boston.

Eurydice (2007). The Education System in the Netherlands 2006/2007 Eurydice. Directorate-general for education and culture.

Gal-Ezer, J. (1995). Computer science teachers' certification program. Computers \& Education, 25, 163-168.

Gal-Ezer, J., Beeri, C., Harel, D. and Yehudai, A. (1995). A high-school program in computer science. Computer, 28, 73-80.

Hacquebard, A., Zwaneveld, B., van Dijk, B., van Leeuwen, H. and Timmers, J. (2005). Keuzevak Informatica in de Tweede Fase HAVO en VWO, Opstap naar de kennismaatschappij. CODI. Ref Type: Pamphlet.

Hartsuijker, A. (1999). Syllabus Informatica Arnhem, Cito.

Hartsuijker, A. (2001). Vakdossier Informatica 2000 Enschede, SLO.

Hartsuijker, A. (2002). Vakdossier Informatica 2001 Enschede, SLO

Hartsuijker, A. (2003). Vakdossier Informatica 2002 Enschede, SLO

Hartsuijker, A. (2004). Vakdossier Informatica 2003 Enschede, SLO.

Hartsuijker, A., Bosschaart, E., Deinum, J.F., Dijk, B.v. and Westeringh, W.v.d. (2000). Vakdidactiek Deel 1 CODI.

Hulsen, M., Wartenbergh-Cras, F., Smets, E., Uerz, D., van der Neut, I., Sontag, L. et al. (2005). ICT in Cijfers (in English, ICT in Figures). IVA, Nijmegen, ITS.

Meijer, H., Hart, T. and Reinders, H. (2001). Turing. ThiemeMeulenhoff, Utrecht/Zutphen.

Ministry of Education, C. a. S. (1998a). Omscholing informatica. Cfi.

Ministry of Education, C. a. S. (6-5-1998b). Vaststelling examenprogramma's vwo/havo. Decision 6.1-Decision 6.2. Ref Type: Statute.

Profile board Nature \& Profile board Society (2007). Bridges between Nature and Society.

Schmidt, V. (2006). Handreiking schoolexamen informatica havo/vwo Enschede, SLO.

Schmidt, V. (2008). Vakdossier 2007 Informatica Enschede, SLO.

Stuurgroep Profiel Tweede Fase Voortgezet Onderwijs (1994). De Tweede Fase vernieuwt: Scharnier tussen basisvorming en hoger onderwijs. Rep. No. 2. Den Haag.

Stuurgroep Profiel Tweede Fase Voortgezet Onderwijs (1995). Advies Examenprogramma's havo/vwo Informatica. Den Haag: MinOC\&W.

Tolboom, J. (1999). The first year of the CODI curriculum. Informatie bulletin I\&I, 11, 9-11.

Tweede Fase Adviespunt (2006). Veranderingen Tweede Fase en docenten: volgen of meebeslissen. www. tweedefase-loket. doc [on-line].

Van der Laan, J., Krikke, H., Kievit, D., \& Bosschaart, E. (2001). Fundament Informatica (2 ed.). Instruct, Bodegraven.

Van Weert, T., Tinsley, D. (1994). Informatics for Secondary Education, A curriculum for schools. UNESCO, Paris.

Van Weert, T., Tinsley, D. (2000). Information and Communication Technology in Secondary Education, A curriculum for schools. UNESCO, Paris. 
N. Grgurina has a degree in mathematics and informatics. She began her career as a high school mathematics teacher. She presently teaches informatics at a high school and the didactics of informatics at the University Centre for Learning and Teaching of the University of Groningen.

J. Tolboom is a lecturer in mathematics and education of mathematics and computer science at the University of Groningen.

\section{Pirmasis informatikos dešimtmetis olandu vidurinèse mokyklose}

\section{Nataša GRGURINA, Jos TOLBOOM}

Beveik visose pasaulio vidurinèse mokyklose yra mokoma informatikos. Nyderlanduose, vidurinių mokyklų mokiniai kompiuterinio raštingumo išmoksta žemesnèse klasėse. Kompiuterinis raštingumas čia nèra įtraukiamas į informatikos dalyko kursą. Straipsnyje keliami šie klausimai: Ar informatikos dalykas turi būti mokomas aukštesnèse klasėse? Ko turètu būti mokoma, kas turètu mokyti ir kaip? Kaip turètų būti vertinami mokiniu pasiekimai? Šie klausimai yra pagrindžiami tyrimais. Straipsnyje taip pat nusakomi ir aptariami informatikos mokymo tikslai, pateikiamas Nyderlandų vidurinių mokyklų informatikos dalyko turinys, aprašoma jo sukūrimo svarba. 